\title{
The Effects of Non-Digital Game-Based Learning on Brunei Darussalam Students' Mathematical Perspectives and Achievements
}

\author{
${ }^{1}$ Nurul Aqilah Mohd. Yusof \& ${ }^{1}$ Masitah Shahrill \\ ${ }^{1}$ Sultan Hassanal Bolkiah Institute of Education, Universiti Brunei Darussalam, Brunei Darussalam \\ ${ }^{1}$ masitah.shahrill@ubd.edu.bn
}

\begin{abstract}
The purpose of this study is to investigate the effectiveness of a non-digital game-based learning approach by assessing the differences in students' achievement score between the pre-test and the post-test on the topic of multiplication and division with indices. A paired sample t-test was used to investigate a significant difference in the students' achievements after implementing the non-digital game-based learning intervention. A total of 35 students from two classes of nine grade students in one of the secondary schools in Brunei Darussalam was involved in the study. Another aim of this study was to investigate the students' perspectives on using a nondigital game-based learning approach in their learning process. This was analysed through the questionnaire and interviews. The results showed that the integration of a non-digital gamebased learning approach in the mathematics lesson did have a positive effect on the students' achievement scores. More than half of the students believed that the game has helped them to improve their Mathematical skills.
\end{abstract}

Keywords: Non-Digital Game-Based Learning, Multiplication and Division with Indices, Achievement Scores, Students' Perspectives

\section{Introduction}

By using games, the "Knowledge delivered through games has a profound effect on the younger generation in every aspect, such as their mind, physical appearance, and behavior" (Amdan \& Salleh, 2016, p. 3963). Non-digital games do not require direct interaction with computers or digital devices (Naik, 2017). Examples of non-digital games include board games, card games, MathEscape (Glavaš \& Staščik, 2017) and Sliding a Picture (Rondina \& Roble, 2019). The integration of games in teaching, including the teaching of mathematics, has a long history (Naik, 2017) and has been used in several studies, such as Prahmana, Zulkardi, and Hartono (2012) and Jaelani, Putri, and Hartono (2013); and recent studies, for example by Maharani, Putri, and Hartono (2019), Risdayanti, Prahmana, and Shahrill, (2019), and Brezovsky et al. (2019). Some students find mathematics hard and boring, which killed their interest in learning the subject. Increasing learning interest in mathematics can be accomplished in several ways, one of which is to integrate the teaching of mathematics with educational games (Glavaš \& Staščik, 2017).

The purpose of this study is to explore the effectiveness of non-digital game-based learning approach on the achievements of two classes of nine-grade Brunei students by assessing the score differences between the pre-test and the post-test. This study also investigated the students' perspectives on using a non-digital game-based learning approach in their learning process. This study aims to promote a student-centred learning environment as it is one of the 
pedagogical dimensions in the national education system of Brunei Darussalam called Sistem Pendidikan Negara Abad ke-21, SPN21. The SPN21 serves as a platform to sustain the Ministry's continuous commitment in providing quality education for the nation (Ministry of Education, 2013). This research is guided by the following research questions: What significant statistical differences can be found in the students' achievements before and after using the non-digital game-based learning method? And what are the students' perspectives on the nondigital game-based learning method used in their classroom?

\section{Game-Based Learning}

Game-based learning is defined as a primary pedagogical tool that helps to foster soft and technical skills in a structured learning process concept since games can provide some kind of contexts and framework for the learners (Sousa \& Rocha, 2019). It also acts as an active learning environment and encourages learning activities that engage and challenge students to achieve the learning objectives (Romero, Usart, \& Ott, 2015). In addition, in a study using games on mobile devices, the researchers stated that combining learning and game playing may improve the player's ability within the school subject and in applying it to the real world (Liu \& Chu, 2010).

In recent years, there has been an increase of focus on games as games are exciting and create a fun learning atmosphere since the students' experiences and learning are of interest for researchers and educators (Gillern \& Alaswad, 2016). As mentioned by Yang, Chu, and Chiang (2018), from educational games, learners can gain enjoyment, self-confidence and satisfaction if their skills and knowledge in game-based learning are equal to the given challenging tasks.

\section{Game-Based Learning and Achievements}

Through game-based learning, students can generate bright interaction and facilitate their learning motivation as well as learning achievement (Qian \& Clark, 2016). Previous studies using digital game-based learning have shown that students gained improvement in terms of their achievement in a number of areas. Setyaningrum, Pratama, and Ali (2018) studied 113 eight-grade students from three junior high schools in Yogyakarta. The students who used the game-based learning with smart phones in terms of a problem-solving approach significantly outperformed those students who used a problem-solving approach using a textbook based pedagogy. Meanwhile Park, Kim, Kim, and Yi (2019), studied 64 university students using an arrow-shooting game in the context of English vocabulary learning and reported a significant increase in the level of learning, motivation and engagement. Naik (2017) studied the use of non-digital games to instruct first-year BSc Computer Science students who lacked experience of formal mathematical instruction beyond elementary levels. Naik reported improved examination results and positive student feedback concerning the learning experience. Turgut and Temur (2017) studied the effects of game-assisted mathematics education on academic achievements in Turkey using the meta-analysis approach where the results inferred that using games in teaching mathematics generally had a positive effect on the students' achievements.

As a matter of fact, previous studies have shown positive effects in using game-based learning approach, in a way that game-based learning has been implemented as one of the teaching strategies; however, the effectiveness of the approach remains unclear (Law \& Chen, 
2016). Furthermore, the fact that students have different interest may lead them to consider the games as either interactive or not, engaging or not. Some students may find it more comfortable to work using drilling and conventional practice since this is the kind of learning method they have ever implemented since primary schools. Another concern is the fact that having games in class would take a lot of time in the students' learning process depending on their achievement and developmental differences, and thus at the same time, some students would be reluctant to participate in the study (Fitriah, 2018).

Although the use of game-based learning is popular, most of the games are digital. Therefore, many areas on non-digital game-based are unexplored. Previous studies using digital game-based learning suggests positive results on students' learning in terms of their performance, but there are still much to be explored on how the non-digital game-based has any effect on the students' performance. Although there was no previous study to report students' improvement in mathematical achievement after the introduction and utilization of game-based learning method, be it the digital or non-digital games, this present study may give some indication that the assumption may be correct.

\section{Methods}

\section{Research Design}

The research design is based on an action research approach. Action research has been used for empowering teachers since it is a significant medium (Cohen, Manion, \& Morisson, 2011). Action research operates in cycles of planning, executing and fact-finding, as it is a significant feature and it is used as a way of representing action research (McNiff, Lomax, \& Whiteheard, 1996). Denscombe (2010) believed that it is a commitment to a research process where the findings application and the practice evaluation's impact become part of the research cycle. This action research was executed in two cycles. The first cycle was conducted in Class A and the second cycle in Class B.

\section{Sample}

The study was conducted in one of the government secondary schools in the Brunei-Muara district, with a sample of nine-grade mathematics students. There were nine students who were eliminated due to absenteeism, consequently, only data of 35 students were analysed in the study (refer to Table 1).

Table 1

The number of participants in Class A and Class B

\begin{tabular}{lccc}
\hline & Male & Female & Total \\
\hline Class A & 9 & 6 & 15 \\
Class B & 9 & 11 & 20 \\
\hline
\end{tabular}

\section{Instruments}

The pre-test and post-test papers were created to measure the students' achievement scores. Reliability test was not conducted since the questions were from past year examination paper questions. Validity of the test papers was also checked by experienced teachers. Questions on 
the test papers depend on the specific topic. The topic chosen was on multiplying and dividing with indices. After the post-test, a questionnaire was given to all participants to acquire their perspectives on non-digital game-based learning. Interviews were also conducted to seek participants' feedback and their preference for non-digital game-based learning. The interviewees were selected based on the students' achievement scores.

\section{Lesson Interventions}

The first author conducted the lesson interventions in the two classes that she taught. Each lesson was around 50 to 55 minutes. An instruction card was needed as well to ease students to refer back during the game lesson. The students were divided into pairs and some into a group of three. The game introduced was known as 'Break the Code' Game (refer to Figure 1) adapted from the 'Rules for Indices (Treasure Hunt)' (Maths4Everyone, 2018). Each pair was given 16 cards. The first card was the 'START' card and students had to find out the answer to its question. The students found the card with the answer of the first card and answer its question, putting this second card, next to the first card. The students then had to repeat the process of finding the answer until they had answered all the questions on all of the cards. Afterwards, the students would use the deciphering table to change the letters from their answers into the letters of the actual message, which is a clue to where the next set of cards were hidden. The difficulty of the game increased by providing them with more complicated mathematical expressions.

\begin{tabular}{|c|c|c|c|c|c|c|c|c|c|}
\hline START & $3^{12}$ & $5^{10}$ & $3^{6}$ & 2 & & $5^{7}$ & 7 & & 1 \\
\hline $\begin{array}{l}\text { Simplify } \\
\qquad 3^{2} \times 3^{10}\end{array}$ & $\begin{array}{l}\text { Simplify } \\
\quad 5^{6} \times 5^{4}\end{array}$ & $\begin{array}{l}\text { Simplify } \\
\qquad 3^{3} \times 3^{3}\end{array}$ & $\begin{array}{l}\text { Simplify } \\
\quad 7^{-10} \times 7^{9}\end{array}$ & $\begin{array}{l}\text { Simplify } \\
\qquad \frac{5^{10}}{5^{3}}\end{array}$ & & $\begin{array}{l}\text { Simplify } \\
\qquad 7^{10} \div 7^{9}\end{array}$ & $\begin{array}{l}\text { Simplify } \\
\qquad \frac{3^{9}}{3^{9}}\end{array}$ & & $\begin{array}{l}\text { Simplify } \\
\qquad 5^{9} \div 5^{8}\end{array}$ \\
\hline $\begin{array}{c}\text { Brack the } \\
\text { C@D }\end{array}$ & $\begin{array}{c}\text { Breat the } \\
\text { CODE }\end{array}$ G & $\begin{array}{c}\text { Breat the } \\
\text { CODEE }\end{array}$ & $\begin{array}{l}\text { Breat the } \\
\text { CODDE }\end{array}$ & COane the & $Y$ & $\begin{array}{l}\text { Breat the } \\
\text { COODE }\end{array}$ & $\begin{array}{l}\text { Bruat the } \\
\text { ¿@DE⿷匚⿳丨コ丨 }\end{array}$ & L & $\begin{array}{l}\text { Byneret the } \\
\text { CODDE }\end{array}$ \\
\hline $7^{-1}$ & $3^{8}$ & 8 & 9 & 5 & & $7^{3}$ & 0 & & 4 \\
\hline $\begin{array}{l}\text { Simplify } \\
\qquad 3^{4} \times 3^{4}\end{array}$ & $\begin{array}{l}\text { What is the value } \\
\text { of } n^{2} \\
\qquad 5^{n} \times 5^{6}=5^{14}\end{array}$ & $\begin{array}{l}\text { What is the value } \\
\text { of } n^{n} \\
7^{3} \times 7^{n}=7^{12}\end{array}$ & $\begin{array}{l}\text { What is the value } \\
\text { of } n^{2} \\
3^{2} \times 3^{n}=3^{4}\end{array}$ & $\begin{array}{l}\text { Simplify } \\
\qquad 7^{5} \div 7^{2}\end{array}$ & & $\begin{array}{l}\text { What is the valu } \\
\text { of } n^{2} \\
5^{6} \div 5^{n}=5^{6}\end{array}$ & $\begin{array}{l}\text { What is the valu } \\
\text { of } n^{2} \\
\qquad \frac{3^{10}}{3^{n}}=3^{6}\end{array}$ & & FINISH \\
\hline 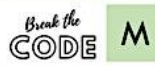 & CODDE & $\begin{array}{c}\text { Breat the } \\
\text { CODDE }\end{array}$ & $\begin{array}{c}\text { Breat the } \\
\text { CODDE }\end{array}$ & $\begin{array}{l}\text { Bract the } \\
\text { C@DDE }\end{array}$ & $M$ & $\begin{array}{l}\text { Binet the } \\
\text { C@DE }\end{array}$ & $\begin{array}{l}\text { Bruat the } \\
\text { C@D医 }\end{array}$ & L & $\begin{array}{c}\text { Burat the } \\
\text { C@D區 } C\end{array}$ \\
\hline
\end{tabular}

Figure 1. Break the Code set of cards.

\section{Data Collection}

Mathematical achievement was collected through students' assessment. A pre-test was given to the students each with one lesson prior to the intervention. The paired sample t-test was used to test the comparison of the pre-test and post-test scores. Meanwhile, the post-test was administered a few days after the lesson intervention. The level of difficulty of both pretest and post-test paper was maintained to compare the students' scores. The questions used in the post-test were the same as the pre-test; however, the coefficients and variables in the questions were changed.

After the post-test was conducted, a questionnaire was disseminated to all students seeking their perspectives on non-digital game-based learning. A 10-minute interview, consisted of 8 
questions, was conducted and only a few students were selected to be interviewed depending on their achievement scores. The interviews were recorded and transcribed.

\section{Data Analysis}

The paired sample t-test was used to test for statistical significance of mean score difference of pre-test and post-test. To give a valid result, four assumptions are required before using paired sample t-test. The first assumption is where the dependent variable, the achievement scores must be on a continuous scale. Secondly, the independent variable must consist of two related groups, or, by having same subjects in both groups. In other words, same students attempted both the pre-test and the post-test. Thirdly, there should be no significant outliers in the difference between the two related groups. As a result, there was no outliers in the data of this study. Lastly, the distribution of the differences in the achievement scores between the two related groups should be approximately normally distributed. Shapiro Wilk test will be conducted first to assess the data's normality. The effect size, which is the ETA squared, was calculated for Class A and Class B.

\section{Results and Discussion}

\section{Comparison between Pre-Test and Post-Test of Class A}

Table 2 shows the mean and standard deviation of pre-test and post-test of Class A. The results showed that mean score difference of the pre-test and post-test were 4.667 and 8.067 respectively. The increase in the mean shows that students improved in their post-test. The standard deviation of the pre-test was 2.024 and the post-test was 2.219.

Table 2

The mean and standard deviation of pre-test and post-test of Class A

\begin{tabular}{llcccc}
\hline & N & Mean & $\begin{array}{c}\text { Standard } \\
\text { Deviation }\end{array}$ & $\begin{array}{c}\text { Std. Error } \\
\text { Mean }\end{array}$ \\
\hline Class A & Pre-test & 15 & 4.667 & 2.024 & 0.523 \\
& Post-test & 15 & 8.067 & 2.219 & 0.573 \\
\hline
\end{tabular}

The results in Table 3 demonstrates a significant difference in students' achievement scores between the pre-test and post-test with a $p$-value of 0.000 . The mean increase in the scores was 3.4 with a $95 \%$ confidence interval ranging from 2.423 to 4.377 . With an effect size of 0.799 , this indicates that it has a moderate effect and it shows that the non-digital game-based learning method works for Class A in particular.

Table 3

Paired sample t-test between pre-test and post-test for Class A 


\begin{tabular}{|c|c|c|c|c|c|c|c|c|}
\hline & \multirow[b]{2}{*}{ Mean } & \multirow[b]{2}{*}{$\begin{array}{l}\text { Standard } \\
\text { Deviation }\end{array}$} & \multirow[b]{2}{*}{$\begin{array}{c}\text { Std. Error } \\
\text { Mean }\end{array}$} & \multicolumn{2}{|c|}{$\begin{array}{l}\text { 95\% Confidence } \\
\text { Interval of the } \\
\text { Difference }\end{array}$} & \multirow[b]{2}{*}{$t$} & \multirow[b]{2}{*}{$\mathrm{df}$} & \multirow[b]{2}{*}{$\begin{array}{l}\text { Sig. (2- } \\
\text { tailed) }\end{array}$} \\
\hline & & & & Lower & Upper & & & \\
\hline Class A & 3.400 & 1.765 & 0.456 & 2.423 & 4.377 & 7.462 & 14 & 0.000 \\
\hline
\end{tabular}

Figure 2 shows the bar graph of total scores obtained by Class A students for their pre-test. Majority of the students achieved a score of 5. However, a total of six out of 16 students failed the pre-test. No students managed to get full scores since the highest score was 8 , in which only one student achieved the score.

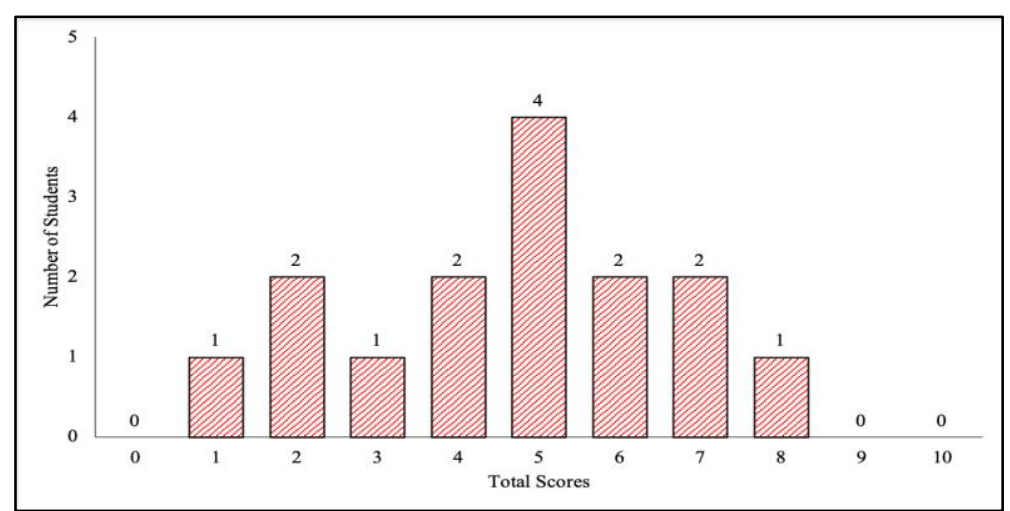

Figure 2. A bar graph showing the total scores of Class A students for pre-test.

For the post-test (refer to Figure 3), all of the students improved their scores. Five students managed to get a score of 10. Only two students failed the test (achieving below the average score of 5). Although there were still failures, every student improved their scores, since all of the score difference of each student was positive.

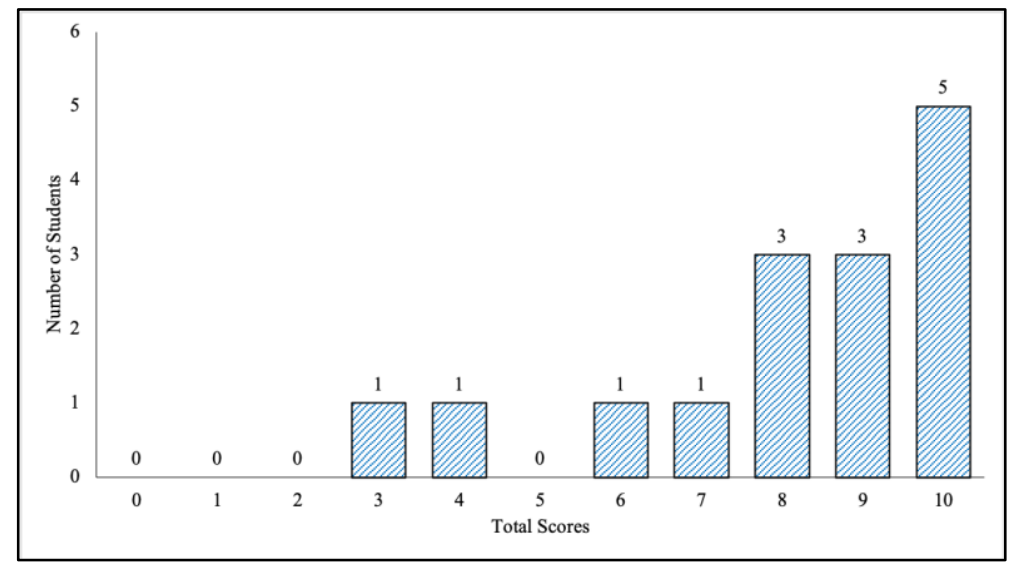

Figure 3. A bar graph showing the total scores of Class A students for post-test.

Figure 4 shows a bar graph of the total scores obtained by each student in their pre-test and post-test. Every student improved their scores as there was no decrease in the scores from their pre-test. Student 15 obtained a large difference in the score, which increased from 1 to 8 . Student 1 and Student 2 only managed to improve their score by 1. 


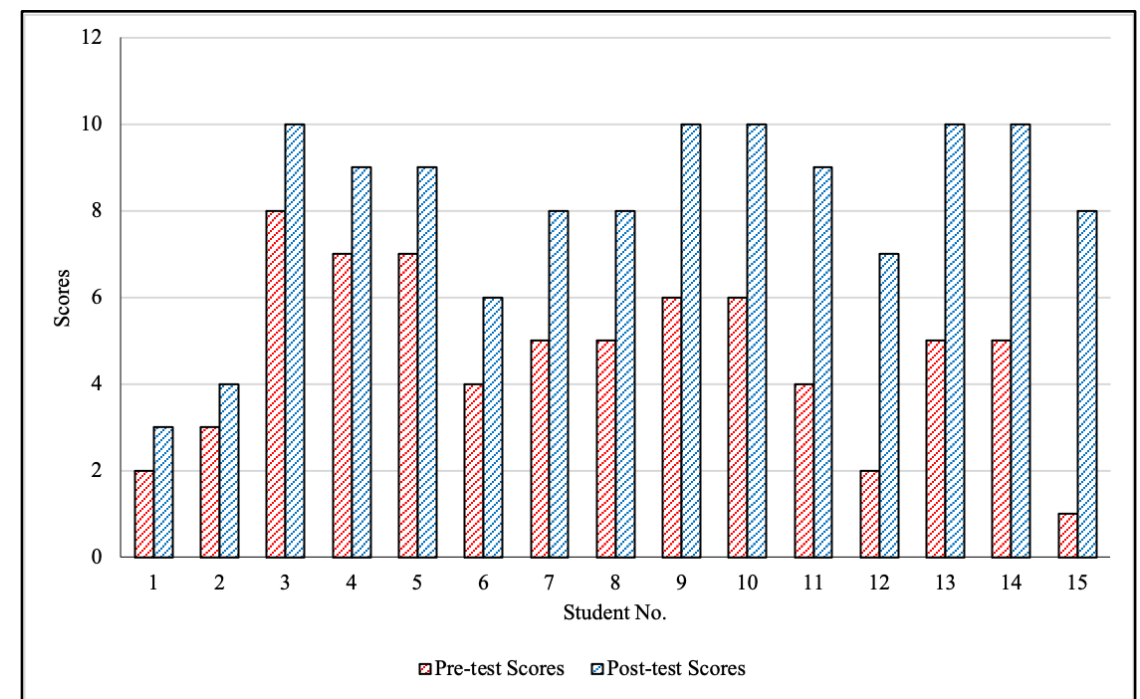

Figure 4. The total scores obtained by each student in Class A for pre-test and post-test

\section{Comparison between Pre-Test and Post-Test of Class B}

Table 4 shows the mean and standard deviation of pre-test and post-test of Class B. The results showed that the means of the pre-test and post-test were 4.750 and 7.950 respectively. The standard deviation of the pre-test was 2.807 and the post-test was 1.820 . This result also shows that students improved in their post-test.

Table 4

The mean and standard deviation of pre-test and post-test of Class B

\begin{tabular}{llcccc}
\hline & N & Mean & $\begin{array}{c}\text { Standard } \\
\text { Deviation }\end{array}$ & $\begin{array}{c}\text { Std. Error } \\
\text { Mean }\end{array}$ \\
\hline Class B & Pre-test & 20 & 4.750 & 2.807 & 0.628 \\
& Post-test & 20 & 7.950 & 1.820 & 0.407 \\
\hline
\end{tabular}

The results displayed in Table 5 indicate a significant difference in the students' achievements from the pre-test to post-test, with a $p$-value of 0.000 . There is a mean increase of 3.200 with a $95 \%$ confidence interval ranging from 1.989 to 4.411 . An effect size of 0.617 implies a moderate effect, indicating that the non-digital game-based learning method did work in Class B as well.

Table 5

Paired sample t-test between pre-test and post-test for Class B 


\begin{tabular}{|c|c|c|c|c|c|c|c|c|}
\hline & \multirow[b]{2}{*}{ Mean } & \multirow[b]{2}{*}{$\begin{array}{c}\text { Standard } \\
\text { Deviation }\end{array}$} & \multirow[b]{2}{*}{$\begin{array}{c}\text { Std. Error } \\
\text { Mean }\end{array}$} & \multicolumn{2}{|c|}{$\begin{array}{l}\text { 95\% Confidence } \\
\text { Interval of the } \\
\text { Difference }\end{array}$} & \multirow[b]{2}{*}{$t$} & \multirow[b]{2}{*}{ df } & \multirow[b]{2}{*}{$\begin{array}{l}\text { Sig. (2- } \\
\text { tailed) }\end{array}$} \\
\hline & & & & Lower & Upper & & & \\
\hline Class B & 3.200 & 2.587 & 0.579 & 1.989 & 4.411 & 5.531 & 19 & 0.000 \\
\hline
\end{tabular}

Figure 5 shows the bar graph of total scores obtained by Class B students for their pre-test. In the pre-test, eight students failed where two students get zero score. Similar to Class A, no students managed to obtain perfect scores. Three students obtained the highest score which was 8. Majority of the students achieved a score of 7. Meanwhile, for the post-test (refer to Figure 6), only one student failed the test (achieving below the average score of 5), four students achieved the perfect score and five students obtained score of 9.

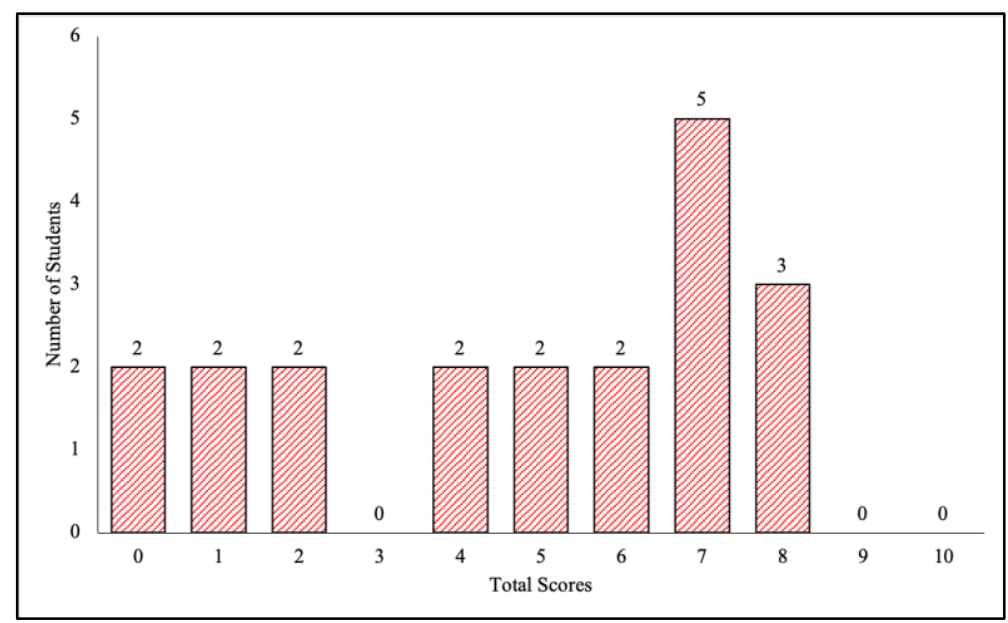

Figure 5. A bar graph showing the total scores of Class B students for pre-test.

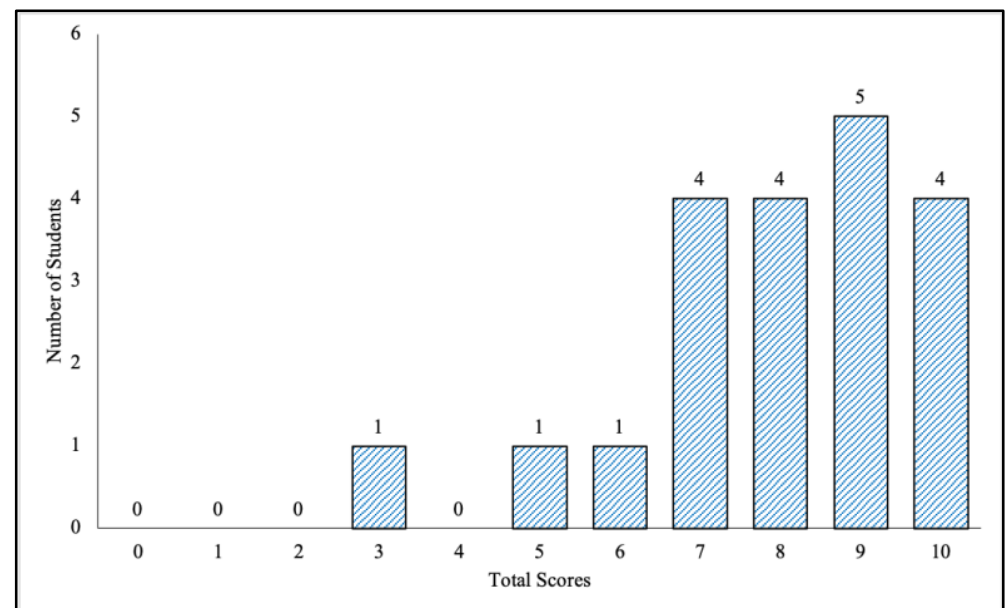

Figure 6. A bar graph showing the total scores of Class B students for post-test.

Figure 7 shows the total scores obtained by each student in their pre-test and post-test. Only one student, which was Student 1, did not manage to improve in the post-test as the score decreased from 7 to 5. Student 2 and Student 3 maintained their scores since they scored 8 for both pre-test and post-test.. The other students' scores showed an increase from their pre-test 
to post-test. The largest score difference was 8 , which was obtained by Student 20, from a score of 2 to 10 .

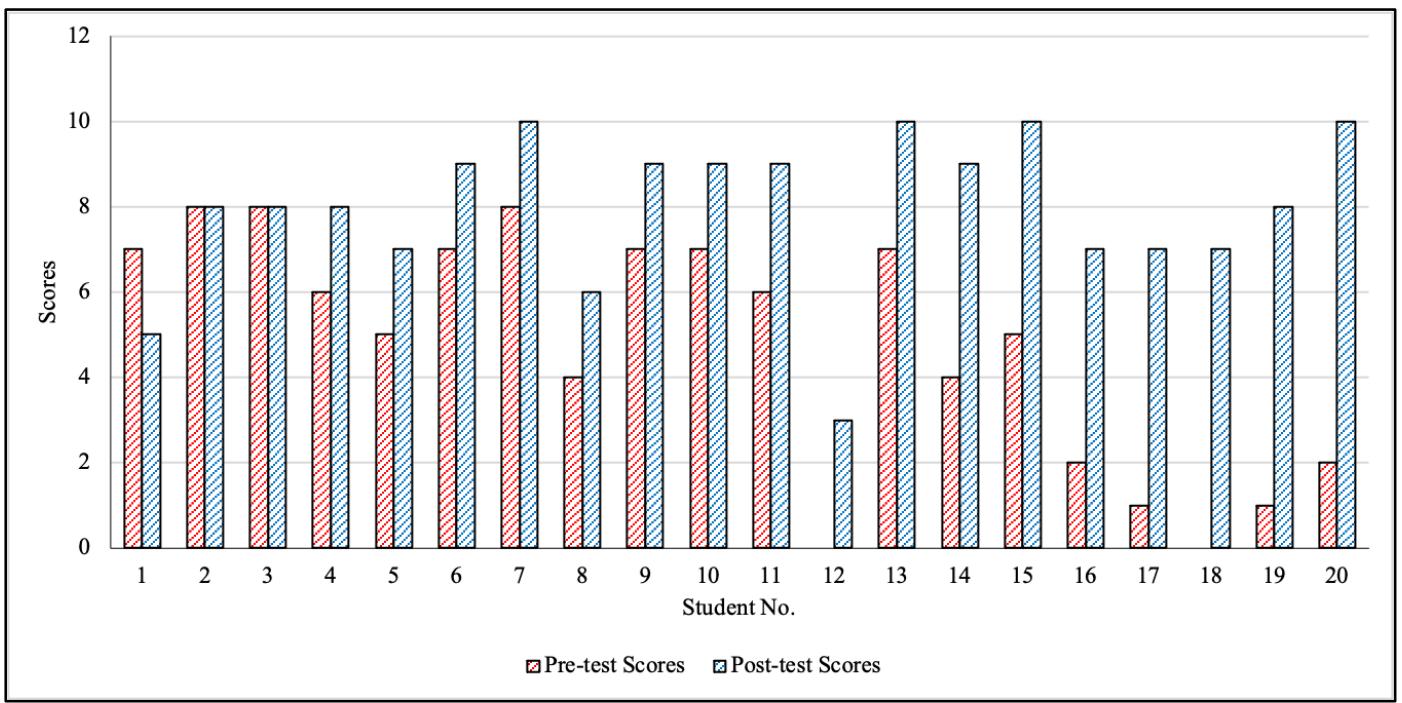

Figure 7. The total scores obtained by each student in Class B for pre-test and post-test.

From the comparison of pre-test and post-test scores, there was an increase in the mean scores for Class A and Class B students. Through the paired sample t-test, it is conclusive that there are statistically significant differences of students' achievements before and after using the non-digital game-based learning method. The results showed that the integration of nondigital game-based learning in the mathematics lesson did have a positive effect on the students' achievement scores. Hence, implementing non-digital game-based learning as one of the lesson interventions to use in a classroom may bring encouraging impact on students' achievements.

\section{Questionnaire and Interview Results}

The students responded to a questionnaire on their gameplay experience in the class. These questionnaire responses were supported by some of the interviewees' responses. The results were divided into categories, which were experience on the gameplay, autotelic experience, and interaction with peers. There were five interviewees; two from Class A and another three from Class B. All the interviewees in Class A improved their score. In other words, they gained a positive score difference. Meanwhile, in Class B, one interviewee improved his score in the post-test, one student's score remained the same, and one student performed worse in post-test than in the pre-test. The interviewees were coded as A15 and A04 for Class A and B18, B06 and B10 for Class B.

Moon and $\mathrm{Ke}$ (2020) defined peer interactions as social interactions among students in a similar age group either verbally or nonverbally. Autotelic experience refers to when the player play the game for great enjoyment, instead of playing with the hope of rewards or external reasons (Zheng, 2012).

Overall, during the interviews, when students were asked about their thoughts on the game, they found that the game was fun and enjoyable. This finding is in line with what was mentioned by Gillern and Alaswad (2016) that the game created a fun learning atmosphere for 
students' experiences and their learning. Most of the students gave the game a rating of 8 out of 10. With this game, students may find the subject fun and interesting as the game helped them to improve their understanding of the given topic, as revealed by some of the students' responses below:

B18: It was really fun for me and my partner...because I am a very competitive person, and yatah macam (thus) ... I like the game.

B06: [laugh] because I don't really like maths that much... yesterday I think it was one of the moments when I like maths.

B10: Because... at first I really don't understand the game but at the end, I started to understand it gradually, and it was... so good.

The students also responded to their feelings when they played the game. They believed that the game improved their skills on the topic and helped them to bond with their partner during the game. One of the students also said that the game has made him more confident. This showed that the game helped students to build more confidence in answering mathematical questions. The responses were:

A15: I felt.... When I played the game I felt so excited and... that helped improve my skills.

B18: It really felt macam (like)... I was challenging myself so I can improve myself and my partner and it helped me and my partner macam (like) bonding jua (also)...really fun for me.

B06: Hmmm what should I say? I think I was a little more confident than the usual

Generally, the students found this game as fun and they believed that they could improve their skills while playing the game. These concurred with Yang et al.'s (2018) statement which mentioned that from educational games, the learners could gain enjoyment, self-confidence and satisfaction if their skills and knowledge in game-based learning are equal to the given challenging tasks.

Referring to Table 6 below, these were the responses from the students on their autotelic experience. More than half of the number of students, or $86 \%$, really enjoyed the game. This statement corresponds with the next statement, in which $83 \%$ of the students like the feeling of playing the game again. When students were asked during the interview, most of them said that they wanted to play the game again in the future. In total, $69 \%$ of the students believed that the game improved their skills and they were able to complete more difficult tasks. Nevertheless, $3 \%$ of the students did not agree with the statement. Probably, the questions given in the game were already challenging in the first place, hence, the given tasks are not equal to their skills. Instead, this could demotivate them to play the game until the end of the session. Moreover, $80 \%$ of the students found it easy to understand how to play the game. The positive responses may indicate that the game is suitable for the students.

Table 6

Students' autotelic experience during gameplay

\begin{tabular}{lllll}
\hline Strongly & Disagree & Neutral Agree & $\begin{array}{c}\text { Strongly } \\
\text { Agree }\end{array}$ \\
\hline
\end{tabular}




\begin{tabular}{lccccc}
\hline I really enjoyed playing the game. & $0 \%$ & $0 \%$ & $14 \%$ & $37 \%$ & $49 \%$ \\
$\begin{array}{l}\text { I liked the feeling of playing and want to } \\
\text { play it again. }\end{array}$ & $0 \%$ & $0 \%$ & $17 \%$ & $40 \%$ & $43 \%$ \\
$\begin{array}{l}\text { As I played the game, my skills got } \\
\text { improved and so I was able to complete } \\
\text { more difficult tasks. }\end{array}$ & $3 \%$ & $0 \%$ & $26 \%$ & $43 \%$ & $26 \%$ \\
$\begin{array}{l}\text { It was easy for me to understand how to play } \\
\text { the game. }\end{array}$ & $0 \%$ & $0 \%$ & $17 \%$ & $54 \%$ & $26 \%$ \\
\hline
\end{tabular}

As this game required the students to play in pairs or a group of three, they were also asked about the interactions with their partners when playing the game (refer to Table 7). There were $86 \%$ of the students who enjoyed playing the game with their partner, whereas $3 \%$ of the students disagreed with the statement. This was probably due to the fact that some students found it uncomfortable playing with some partners they were unfamiliar with, whom they referred as a mere acquaintance, instead of partnering with those whom they were comfortable with. This statement is supported by the following statement in which $68 \%$ of them agreed that their partner helped them to do better in the game. In the interview, the students said that having a partner did help them in answering the questions in the game and it also helped the student to bond with their partner. Some of the responses were:

B18: Yes, because...for... even though it was challenging, I really, really like it. It helped me bond with my partner. Again as I said,... and it was a kind of easy but challenging ...yeah.

B06: Ummm... I did enjoy playing with him because I am used to partnering up with him.

B10: Yes, because he helped me a bit (with) the equation.

With only $6 \%$ of them disagreed with the statement, it is believed that they found that they were not comfortable playing the game with the partner not of their choice. Only $68 \%$ of the students would like to play the game with their partner again in the future. One of the responses, during the interview was "Yes ... because my partner helped me solved the question" (by A15).

A total of $6 \%$ of the students did not agree with the statement about playing the game with the same partner. It is believed that during the interview, one of the students said they should interact with some of the other classmates. The responses were:

B18: Probably... but I would rather try to play it with a different person.

B06: Umm maybe sometime ada (yes) sometime inda (no), because I need to know some other students.

Some believed that it would be better to play with a different partner if they were to play the game again. This showed that students may not prefer to play with their previous partner.

Table 7

Students' interactions with their peers 


\begin{tabular}{lccccc}
\hline & $\begin{array}{c}\text { Strongly } \\
\text { Disagree }\end{array}$ & Disagree & Neutral & Agree & $\begin{array}{c}\text { Strongly } \\
\text { Agree }\end{array}$ \\
\hline I enjoyed playing the game with my partner. & $3 \%$ & $0 \%$ & $11 \%$ & $49 \%$ & $37 \%$ \\
My partner helped me to do better in the game. & $6 \%$ & $0 \%$ & $26 \%$ & $31 \%$ & $37 \%$ \\
$\begin{array}{l}\text { I would like to play the game with my partner } \\
\text { again. }\end{array}$ & $3 \%$ & $3 \%$ & $26 \%$ & $31 \%$ & $37 \%$ \\
\hline
\end{tabular}

More than half of the students believed that the game has helped them to improve their skills. It was also found that students were able to bond with their partner during the game, hence, improving their social skills. As mentioned earlier by Gillern and Asward (2016), nondigital games help to improve social skills since it is a face-to-face interaction. With a face-toface interaction, this also helped to improve their interactions with the teacher (Salam \& Shahrill, 2014; Othman et al., 2015; Shahrill \& Clarke, 2014; 2019).

Although there were positive responses both from the questionnaire and the interviews, some of the students still gave a few disagreements regarding the game. When it came to playing the game, some students did not feel the fast pace of time and some believed the game did not help them to improve the skills on the topic. They felt that the questions in the game were difficult to solve, thus, demotivating them to continue playing the game and just waiting for the game session to be over. Lastly, although more than half of the students preferred to play with their partner again, there were those who preferred to play the game with a different partner in the future. The students also viewed interactions with their peers and the teacher to be important in their learning. Obviously, students may want to play the game in a comfortable environment, in which they do not feel intimidated by their peer. Thus, they would rather choose their peer whom they are comfortable with.

\section{Conclusion}

According to the analysis of the students' achievement scores in the tests, this present study has been able to suggest that the non-digital game-based learning method brought a positive effect on their achievement scores. As for the students' perceptions on the non-digital gamebased learning, despite having a few students who did not agree to some of the statements, more than half actually responded positively. This showed that students do have various learning styles, in which they may or may not prefer games as one of their learning styles approaches.

One of the limitations of this study is the small sample size. Since this is a small-scale study with only 35 students, the generalizability is not significant. Thus, further study could be done or forge links with findings in the area. Furthermore, the achievement scores were only determined by one particular topic on the multiplication and division with Indices, which leads to the impossibility to generalize the results. Another limitation was limited to the single sampled school as the case study. Therefore, more schools could be involved to expand the scope of the study.

In light of the limitations of this study, a few recommendations have been suggested for future research. It is advised to conduct a wide-scale research to obtain better data accuracy of the nine-grade students. Further research on different mathematics topics will need to be 
conducted to see whether this particular game works or not. Sometimes, the approach may not be suitable for that particular topic, and thus a different approach needs to be considered as well. The integration of the game is crucial in the mathematics lesson to have a further study on the effectiveness of the game, which provides an opportunity for the students to adapt to a different kind of learning environment in the classroom.

\section{References}

Amdan, E. F., \& Salleh, S. M. (2016). E-learning applications and computer graphics games for education: Design framework. INFORMATION, 19(19b), 3963-3970.

Brezovszky, B., McMullen, J., Veermans, K., Hannula-Sormunen, M. M., Rodríguez-Aflecht, G., Pongsakdi, N., Laakkonen, E., \& Lehtinen, E. (2019). Effects of a mathematics gamebased learning environment on primary school students' adaptive number knowledge. Computers $\quad \& \quad$ Education, 128, 63-74. https://doi.org/10.1016/j.compedu.2018.09.011

Cohen, L., Manion, L., \& Morrison, K. (2011). Research Methods in Education (7th ed.). Routledge.

Denscombe, M. (2010). The Good Research Guide for small-scale social research projects (4th ed.). Open University Press.

Fitriah, S. (2018). The effect of game-based learning activity and students' attribution on students' vocabulary achievement (A comparative experimental study in the eighth grade of SMPN 269 Central Jakarta) (Master's Thesis). Universitas Islam Negeri Syarif Hidayatullah Jakarta, Indonesia. https://doi.org/.1037//0033-2909.I26.1.78

Gillern, V. S., \& Alaswad, Z. (2016). Games and game-based learning in instructional design. International Journal of Technologies in Learning, 23(4), 1-7. https://doi.org/10.18848/2327-0144/CGP/v23i04/1-7

Glavaš, A., \& Staščik, A. (2017). Enhancing positive attitude towards mathematics through introducing escape room games. In Z. Kolar-Begović, R. Kolar-Šuper, \& L. J. Matić (Eds.), Mathematics Education as a Science and a Profession (pp. 281-293). https://doi.org/10.4324/9781315269528

Jaelani, A., Putri, R. I. I., \& Hartono, Y. (2013). Students' strategies of measuring time using traditional "gasing" game in third grade of primary school. Journal on Mathematics Education, 4(1), 29-40.

Law, V., \& Chen, C. H. (2016). Promoting science learning in game-based learning with question prompts and feedback. Computers and Education, 103, 134-143. https://doi.org/10.1016/j.compedu.2016.10.005

Liu, T. Y., \& Chu, Y. L. (2010). Using ubiquitous games in an English listening and speaking course: Impact on learning outcomes and motivation. Computers and Education, 55(2), 630-643. https://doi.org/10.1016/j.compedu.2010.02.023

Maharani, L., Putri, R. I. I., \& Hartono, Y. (2019). Aquatic in asian games: Context of PISA- 
like mathematics problem. Journal on Mathematics Education, 10(3), 459-470.

Maths4Everyone. (2018). Rules for Indices (Treasure Hunt). Retrieved from https://www.tes.com/teaching-resource/rules-for-indices-treasure-hunt-11763230

McNiff, J., Lomax, P., \& Whiteheard, J. (1996). You and Your Action Research Project. Routledge.

Ministry of Education. (2013). The National Education System for the $21^{\text {st }}$ Century. Berakas: Ministry of Education.

Moon, J., \& Ke, F. (2020). Exploring the relationships among middle school students' peer interactions, task efficiency, and learning engagement in game-based learning. Simulation and Gaming, 1-26. https://doi.org/10.1177/1046878120907940

Naik, N. (2017). The use of GBL to teach mathematics in higher education. Innovations in Education and Teaching International, 54(3), 238-246. https://doi.org/10.1080/14703297.2015.1108857

Othman, H. R. H., Suhaimi, Z., Shahrill, M., \& Mahadi, M. A. (2015). To pair or not to pair: Investigating the dynamics of teacher-student interactions in different classroom settings. Turkish Online Journal of Educational Technology, September, 2015 Special Issue for INTE 2015, 675-684.

Park, J., Kim, S., Kim, A., \& Yi, M. Y. (2019). Learning to be better at the game: Performance vs. completion contingent reward for game-based learning. Computers and Education, 139, 1-15. https://doi.org/10.1016/j.compedu.2019.04.016

Prahmana, R. C. I., Zulkardi, Z., \& Hartono, Y. (2012). Learning multiplication using Indonesian traditional game in third grade. Journal on Mathematics Education, 3(2), 115132.

Qian, M., \& Clark, K. R. (2016). Game-based learning and 21st century skills: A review of recent research. Computers in Human Behavior, 63, 50-58. https://doi.org/10.1016/j.chb.2016.05.023

Risdiyanti, I., Prahmana, R. C. I., \& Shahrill, M. (2019). The learning trajectory of social arithmetic using an Indonesian traditional game. Elementary Education Online, 18(4), 2094-2108.

Romero, M., Usart, M., \& Ott, M. (2015). Can serious games contribute to developing and sustaining 21st century skills? Games and Culture, 10(2), 148-177. https://doi.org/10.1177/1555412014548919

Rondina, J. Q., \& Roble, D. B. (2019). Game-based design mathematics activites and students' learning gains. The Turkish Online Journal of Design Art and Communication, 9(1), 1-7. https://doi.org/10.7456/10901100/001

Salam, N. H. A., \& Shahrill, M. (2014). Examining classroom interactions in secondary mathematics classrooms in Brunei Darussalam. Asian Social Science, 10(11), 92-103.

Setyaningrum, W., Pratama, L. D., \& Ali, M. B. (2018). Game-based learning in problem 
solving method: The effects on student's achievement. International Journal on Emerging Mathematics Education, 2(2), 157-164. https://doi.org/10.12928/ijeme.v2i2.10564

Shahrill, M., \& Clarke, D. J. (2014). Brunei teachers' perspectives on questioning: Investigating the opportunities to 'talk' in mathematics lessons. International Education Studies, 7(7), 1-18. http://dx.doi.org/10.5539/ies.v7n7p1

Shahrill, M., \& Clarke, D. J. (2019). Pedagogical features that influence mathematics classroom practices - A Bruneian perspective. Kasetsart Journal of Social Sciences, 40(2), 341-348.

Sousa, M. J., \& Rocha, Á. (2019). Leadership styles and skills developed through game-based learning. Journal of Business Research, 94, 360-366. https://doi.org/10.1016/j.jbusres.2018.01.057

Turgut, S., \& Temur, Ö. D. (2017). The effect of game-assisted mathematics education on academic achievement in Turkey: A meta-analysis study. International Electronic Journal of Elementary Education, 10(2), 195-206. https://doi.org/10.26822/iejee.2017236115

Yang, K., Chu, H., \& Chiang, L. (2018). Effects of a progressive prompting-based educational game on second graders' mathematics learning performance and behavioral patterns. Journal of Educational Technology \& Society, 21(2), 322-334.

Zheng, M. (2012). Fifth graders' flow experience in a digital game-based science learning environment. The British Journal of Psychiatry, 111(479), 1009-1010. https://doi.org/10.1192/bjp.111.479.1009-a 
40 Southeast Asian Mathematics Education Journal, Volume 11, No 1 (2021) 